\title{
Greening the Highways - Road Way Design That Integrates Transportation Functionality and Ecological Sustainability - Case Study of Port to Port Expressway in Hambantota District
}

\author{
Ranasinghe D.M.S.H.K.* \\ Department of Forestry and Environmental Science, Faculty of Applied Sciences, \\ University of Sri Jayewardenepura, Nugegoda, Sri Lanka \\ *hemanthi.ranasinghe@gmail.com
}

\begin{abstract}
The weight of the road transport sector within an economy is considerable, not only in quantitative terms (tons transported), but also in economic terms such as source of wealth, employment and in terms of support given to other economic activities. Through numerous mechanisms, investments in the road sector benefit the whole society by providing access to territory and allowing poverty alleviation to take place. Consequently, the road network creates and stimulates positive synergy and enhances social cohesion and integration by giving citizens access to the same opportunities. However, in as much as it provides the afore said benefits, if not done holistically without giving proper heed to the environment and natural resources, it poses many negative impacts. Some of them are bifurcating landscapes and societies and calling for involuntary resettlement, impediment on natural hydrology, noise pollution, water pollution, habitat destruction/disturbance and local air quality; and the wider effects including climate change from vehicle emissions. The design, construction and management of roads can change the impacts to varying degrees.
\end{abstract}

A green highway is a roadway constructed with a relatively new concept for roadway design that integrates transportation functionality and ecological sustainability. An environmental approach is used throughout the planning, design, and the construction. The result is a highway that will benefit transportation, the ecosystem, urban growth, public health and surrounding communities. In order to achieve this developer should go beyond the minimum standards set by environmental laws and regulations. First of all it is required to map all the resources in the area in order to avoid, identify and protect critical resource areas. Natural drainage paths need to be protected and restored to protect the hydrology of wetlands and streams in project area. The disruptions to ecological processes should be reduced by promoting wildlife corridors and passages in areas identified through wildlife conservation plans. Examples are taken for the illustration of the above from the recently designed expressway to link the Seaport with the Airport and the Southern Expressway in Hambantota District.

Keywords: Expressway, Environmental impacts, Green highways 